\section{A Ratoon Cropping System for Fall Bell Pepper Production}

\author{
Brian A. Kahn ${ }^{1}$ \\ Department of Horticulture and Landscape Architecture, Oklahoma State \\ University, Stillwater, OK 74078-6027
}

Daniel I. Leskovar

Texas Agricultural Experiment Station, Texas A\&M University, 1619 Garner Field Road, Uvalde, TX 78801-6205

\section{Additional index words. Capsicum annuum, pruning}

\begin{abstract}
Studies were conducted to examine the effects of pruning treatments applied to spring-transplanted bell peppers (Capsicum annuum $\mathrm{L}$.) on marketable fruit yield in late summer and fall. Control plants were set in the field in early May 1997 (Oklahoma) and Apr. 1998 (Oklahoma and Texas) and harvested weekly into October (Oklahoma) or periodically into December (Texas). In 1997, all four treatments (involving height and method of pruning) reduced total marketable fruit weight, but differences among treatments were nonsignificant. In Oklahoma in 1998, plants were mowed on 27 July at an average height of $\approx 24 \mathrm{~cm}$. Mowed plants produced less total marketable fruit weight but more U.S. Fancy fruit than did control plants, while weight of U.S. No. 1 fruit was not affected. In Texas in 1998, plants mowed on $4 \mathrm{Sept}$. at a height of $\approx 20 \mathrm{~cm}$ produced more than twice the weight of U.S. No. 1 fruit and fewer cull fruit than did control plants. Nonpruned transplants set in the field in Summer 1998 (both Oklahoma and Texas) produced low marketable yields. Maintaining spring-transplanted bell peppers is a viable technique for fall pepper production, and the highest total marketable yields may be obtained if these plants are not mowed. However, mowing offers an opportunity for increased fall production of premium fruit, and mowed plants would be easier to manage than nonpruned plants.
\end{abstract}

Ratoon cropping is a system whereby, following an initial harvest period, plants are cut back and allowed to regrow and produce a subsequent crop. Ratooning is a common practice in several cultivated species, including banana (Musa sp.) (Irizarry et al., 1992), rice (Oryza sativa L.) (Coale and Jones, 1994; Jones, 1993), sorghum [Sorghum bicolor (L.) Moench] (McCormick et al., 1995), and sugarcane (Saccharum officinarum L.) (Yadav et al., 1994). Ratooning also has been tested for production of pigeonpea [Cajanus cajan (L.) Huth] (Chauhan et al., 1996) and lima bean (Phaseolus lunatus L.) (Beverly and Byous, 1992). Among the Solanaceae, ratoon cropping sometimes is practiced on eggplant (Solanum melongena L.) (Dhankhar et al., 1980).

Bell pepper typically is grown for spring and fall production in the south-central United States. Growers who target fall markets have a

Received for publication 31 Aug. 2000. Accepted for publication 29 Nov. 2000. Approved for publication by the Director, Oklahoma Agricultural Experiment Station. This research was supported in part under project H-2026. The information given in this publication is for educational purposes only. Mention of a trademark, proprietary product, or vendor does not constitute a guarantee or warranty of the product, nor does it imply approval or disapproval to the exclusion of other products or vendors that may also be suitable. The cost of publishing this paper was defrayed in part by the payment of page charges. Under postal regulations, this paper therefore must be hereby marked advertisement solely to indicate this fact.

${ }^{1}$ To whom requests for reprints should be addressed. choice between maintaining spring-planted peppers through the summer or establishing a summer crop specifically for fall production. The latter option requires additional inputs and is risky because of heat stress conditions during stand establishment.

Unander et al. (1991) suggested that pruning and promotion of crop regrowth could be a low-cost procedure to increase total pepper yields in warm climates where the growing season is long enough to produce a ratoon crop. They conducted a preliminary study in which the additional yield from pruned pepper plants following regrowth was compared to the yield up to the time of pruning. The ratoon system added at least $25 \%$ to the total yield produced in one season. However, no nonpruned plants were maintained and harvested during the period of ratoon crop growth. We expanded on this work by examining different pruning heights and by comparing the yield from continuously harvested, nonpruned control plants with that from ratoon-cropped plants.

\section{Materials and Methods}

The bell pepper cultivar Enterprise was used in these studies. Transplants were commercially grown for spring planting and grown on site for summer planting. In both cases, transplants were produced in flats with inverted pyramid cells (200 cells per flat, volume $18 \mathrm{~cm}^{3}$ per cell).

Studies were conducted at the Vegetable Research Station, Bixby, Okla., in 1997 and
1998 and at the Texas Agricultural Experiment Station, Uvalde, in 1998. The soil at Bixby was a Severn very fine sandy loam [coarse-silty, mixed (calcareous), thermic Typic Udifluvent]. No plastic mulch was used at Bixby. The soil at Uvalde was a Uvalde silty clay loam (fine-silty, mixed, hyperthermic Aridic Calciustoll). Beds in spring-planted treatments at Uvalde were covered with black polyethylene mulch (0.04-mm thickness).

Treatments were arranged in randomized complete blocks with four (Bixby, 1997) or six (both locations, 1998) replications.

\section{Cultural practices and treatments}

Bixby, 1997. The soil was prepared with a broadcast preplant- incorporated application of $39 \mathrm{~N}-17 \mathrm{P}-32 \mathrm{~K}\left(\mathrm{~kg} \cdot \mathrm{ha}^{-1}\right)$, plus trifluralin [2,6-dinitro- $N, N$-dipropyl-4-(trifluoromethyl) benzenamine at $420 \mathrm{~g} \cdot \mathrm{ha}^{-1}$ ] for weed control and diazinon $\{[O, O$-diethyl $O$-[6-methyl-2(1-methylethyl)-4-pyrimidinyl]phosphorothioate at $2.2 \mathrm{~kg} \cdot \mathrm{ha}^{-1}$ \} for soil insect control. Double-row beds (not raised) on 1.7-m centers were used. Rows were $45 \mathrm{~cm}$ apart on the beds and plants were $25 \mathrm{~cm}$ apart within rows. Plots were $5.5 \mathrm{~m}$ long. Data areas were $3 \mathrm{~m}$ long and consisted of the middle 24 plants per bed. Transplants were set in the field by machine on 8 May. No starter solution was used.

Plant water requirements were met with rainfall supplemented by surface drip irrigation. Irrigation began on 16 May and continued throughout the season whenever tensiometers read $>30 \mathrm{kPa}$ at the $30 \mathrm{~cm}$ soil depth. Plants were topdressed with urea to supply $56 \mathrm{~kg} \cdot \mathrm{ha}^{-1} \mathrm{~N}$ on 19 June and 15 Aug. and $34 \mathrm{~kg} \cdot \mathrm{ha}^{-1} \mathrm{~N}$ on 17 July. Standard foliar insect control materials were applied as needed.

Treatments were applied on 8 Aug. as follows: 1) nonpruned (control); 2) mowed; 3) hand-pruned just beneath the first fork of the main stem (MSF); 4) hand-pruned just beyond the first node above the MSF; and 5) hand-pruned just beyond the second node above the MSF. Mowing was done with a flail-vac mower at an average height of $19 \mathrm{~cm}$ above the soil surface. The mowing height, which was $\approx 5 \mathrm{~cm}$ above the average height of the MSF, was designed to be comparable to the pruning height of treatment 4 . After treatments were applied, five plants per plot were measured from the soil to the highest growing point or highest cut.

Selective hand harvests of mature green fruits were made weekly beginning on 14 July and continuing through 21 Oct. (thus there were four harvests in all plots before treatments were applied). Fruits were classified as U.S. Fancy, U.S. No. 1, U.S. No. 2, and culls, according to U.S. Dept. of Agriculture (USDA) grading standards. Cull fruits were misshapen, small, sunburned, or diseased.

Bixby, 1998. The soil was prepared with a broadcast preplant- incorporated application of $36 \mathrm{~N}-16 \mathrm{P}-30 \mathrm{~K}\left(\mathrm{~kg} \cdot \mathrm{ha}^{-1}\right)$, plus trifluralin $\left(560 \mathrm{~g} \cdot \mathrm{ha}^{-1}\right)$. Plot lay-out was similar to that used in 1997. Transplants were set in the field by hand on $20 \mathrm{Apr}$. Each plant received $\approx 200 \mathrm{~mL}$ of starter solution providing 
1079N-941P-895K $\left(\mathrm{mg} \cdot \mathrm{L}^{-1}\right)$, plus diazinon (300 $\left.\mathrm{mg} \cdot \mathrm{L}^{-1}\right)$. Seeds of 'Enterprise' also were sown in flats in a greenhouse on 18 May to produce plants to be set in the field in June. These were plug-type transplants very similar to those used in April. June-set transplants were planted by hand in the field on 25 June, using the same starter solution as that used in April minus the diazinon (soil insects were a minimal threat in June).

Drip irrigation began on 12 May. April-set plants were topdressed with urea to supply 56 $\mathrm{kg} \cdot \mathrm{ha}^{-1} \mathrm{~N}$ on 3 June and $34 \mathrm{~kg} \cdot \mathrm{ha}^{-1} \mathrm{~N}$ on 3 July. Both April-set and June-set plants were topdressed with urea to supply $56 \mathrm{~kg} \cdot \mathrm{ha}^{-1} \mathrm{~N}$ on 5 Aug. and $34 \mathrm{~kg} \cdot \mathrm{ha}^{-1} \mathrm{~N}$ on 8 Sept. All plants also were sprayed with a foliar fertil-

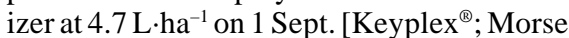
Enterprises, Miami (analysis-4\% S, 3.5\% $\mathrm{Fe}, 1.5 \% \mathrm{Mg}, 0.75 \% \mathrm{Mn}, 0.75 \% \mathrm{Zn}, 0.16 \%$ $\mathrm{B}, 0.006 \% \mathrm{Cu}$, and $0.003 \% \mathrm{Mo})$ ]. Standard foliar insect and disease control materials were applied as needed.

Treatments were: 1) April-set, nonpruned (control); 2) April-set, mowed; and 3) Juneset, nonpruned. Plants were mowed on 27 July with a flail-vac mower at an average height of $24 \mathrm{~cm}$ above the soil surface, which was $\approx 10$ $\mathrm{cm}$ above the average height of the MSF. The few fruits remaining on pruned plants were removed by hand; most were damaged, and experience from the 1997 experiment showed that even intact fruits on pruned plants would soon be sunburned. After mowing, five plants per plot were measured from the soil to the highest growing point or highest cut.

Fruits were harvested and graded as in 1997, beginning on 30 June and continuing through 26 Oct. There were four harvests in April-set plots before mowing. In addition, a final inventory of plots was performed on 29 Oct. Plant health was visually estimated and final stands were recorded. "Healthy" plants lacked putative virus symptoms and were not chlorotic or stunted. Four "healthy" plants per plot were cut at soil level and shoot fresh weights were recorded.

Uvalde, 1998. The soil was prepared with a broadcast preplant- incorporated application of $45 \mathrm{~N}-45 \mathrm{P}-45 \mathrm{~K}\left(\mathrm{~kg} \cdot \mathrm{ha}^{-1}\right)$. No herbicide was used. Three double-row raised beds $(15 \mathrm{~cm}$ high) on 1.9-m centers were used per treatment. Rows were $30 \mathrm{~cm}$ apart on the beds and plants were $33 \mathrm{~cm}$ apart within rows. Plots were $7.5 \mathrm{~m}$ long. Data areas were $6 \mathrm{~m}$ long and consisted of 36 plants in the center bed of each treatment. Transplants were set in the field by a semiautomatic transplanter on 8 Apr. Each transplant received $\approx 50 \mathrm{~mL}$ of starter solution providing $1055 \mathrm{~N}-230 \mathrm{P}-876 \mathrm{~K}\left(\mathrm{mg} \cdot \mathrm{L}^{-1}\right)$. A second batch of transplants was set in the field on 25 July. However, plant survival was very low because of extreme $\left(>38^{\circ} \mathrm{C}\right)$ air temperatures after transplanting, and this treatment was lost. A new batch of transplants was produced, and these plants were set in the field on 4 Sept.

Plant water requirements were met with rainfall supplemented by surface drip irrigation, beginning immediately after transplanting. Fertilizer was applied weekly through the drip system for 6 weeks using $\mathrm{KNO}_{3}$ and
$\mathrm{H}_{3} \mathrm{PO}_{4}$ as sources of $\mathrm{K}, \mathrm{N}$, and $\mathrm{P}$, respectively to totals of $60 \mathrm{~N}-30 \mathrm{P}-78 \mathrm{~K}\left(\mathrm{~kg} \cdot \mathrm{ha}^{-1}\right)$. An additional $20 \mathrm{~kg} \cdot \mathrm{ha}^{-1}$ of $\mathrm{N}$ was applied on 6 Sept. Standard foliar insect control materials were applied as needed.

Treatments were: 1) April-set, nonpruned (control); 2) April-set, mowed; and 3) September-set, nonpruned. A rotary shredder was used on 4 Sept. to mow plants at an average height of $\approx 20 \mathrm{~cm}$ above the bed surface, which was typically one to two nodes above the MSF.

Mature green fruits were selectively handharvested. There were two harvests in Aprilset plots (26 June and 21 July) before mowing. Control plots also were harvested on 24 Sept. and 4 Dec., while mowed plots were harvested on 4 Dec. and September-set plots were harvested on 18 Dec. Fruits were graded according to USDA standards, as in Oklahoma.

Statistical analysis. Each of the three studies was analyzed separately. Data were evaluated by analysis of variance procedures. Duncan's multiple range test (DMRT) was used for mean separation when more than two treatments were compared.

\section{Results}

Cumulative yields from pre-pruning harvests revealed no differences in marketable or total fruit weight between plots to which treatments would later be applied in all three experiments (data not presented); the lowest and highest means for total weight differed by $\leq 0.5$ $\mathrm{Mg} \cdot \mathrm{ha}^{-1}$.

Bixby, 1997. Plant height following pruning differed among the four pruned treatments (Table 1). Mowed plants were reduced in height by $\approx 62 \%$ relative to control plants. Mowed plants and those pruned above the MSF were very similar in height, but were taller than those pruned just below the MSF (the average height of the MSF was $\approx 14 \mathrm{~cm}$ ).

All pruning treatments reduced fruit yield relative to the control for every category except U.S. Fancy fruit (Table 2). Despite the differences in height after pruning, there were very few yield differences among the four pruning treatments. Total number of fruit produced, however, was least when plants were pruned below the MSF (Table 2).

Bixby, 1998. Mowed plants were reduced in height by $\approx 64 \%$ relative to control plants (Table 1), and were taller than June-set plants, which had only been in the field about a month at the time of measurement. The average height of the MSF in April-set plants was $\approx 14 \mathrm{~cm}$, as in 1997.

Mowed plants produced greater weights and numbers of U.S. Fancy fruit than did control plants (Table 2). Mowed plants yielded less than control plants in all other categories except weight of U.S. No. 1 fruit. June-set plants produced the lowest weights and numbers of total marketable fruits and total fruits (Table 2).

The final inventory on 29 Oct. revealed no differences between treatments for total plant stands (data not shown; averages were $>88 \%$ of original stand). There were more "healthyappearing" plants in the June-set plots (4.0
Table 1. Height of bell pepper plants following pruning treatments, Bixby, Okla. ${ }^{2}$

\begin{tabular}{|c|c|}
\hline Treatment $^{y}$ & Plant height $(\mathrm{cm})$ \\
\hline \multicolumn{2}{|c|}{1997} \\
\hline Control & $50 \mathrm{a}$ \\
\hline Mowed & $19 \mathrm{~b}$ \\
\hline Pruned $<$ MSF & $14 \mathrm{c}$ \\
\hline Pruned MSF + 1 & $20 \mathrm{~b}$ \\
\hline Pruned MSF + 2 & $20 \mathrm{~b}$ \\
\hline Significance & $* *$ \\
\hline
\end{tabular}

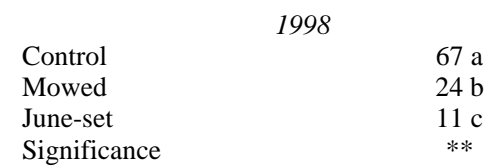

${ }^{\text {zMean separation within years by Duncan's multiple }}$ range test, $P \leq 0.05$.

y1997: All treatments planted in May; control = nonpruned; mowed = flail-vac mowed; pruned < MSF = hand-pruned just beneath the first fork of the main stem (MSF); pruned MSF + 1 = hand-pruned just beyond the first node above the MSF; pruned $\mathrm{MSF}+2=$ hand-pruned just beyond the second node above the MSF. 1998: Control = April planted, nonpruned; mowed = April planted, flail-vac mowed; June-set = June planted, nonpruned

${ }^{* *}$ Significant by $\mathrm{F}$ test at $P \leq 0.01$.

plants $/ \mathrm{m}^{2}$ ) than in the April-set plots (3.1 and 2.7 plants $/ \mathrm{m}^{2}$ for the mowed and control plots, respectively), but the two April-set treatments did not differ from one another (analysis not presented). Shoot fresh weights (kg/plant), with mean separation by Duncan's multiple range test at $P \leq 0.05$, were: control, 0.89 a; mowed, $0.64 \mathrm{a}$; June-set, $0.21 \mathrm{~b}$.

Uvalde, 1998. Mowed plants produced more than twice the weight of U.S. No. 1 fruit and a much lower number and weight of cull fruit than did control plants (Table 3). Total marketable and overall total fruit weights did not differ between control and mowed plants, but control plants produced more total fruits than did mowed plants because of greater production of U.S. No. 2 and cull fruits (Table $3)$. Total marketable yields from Septemberset plants were so low $\left(<3.0 \mathrm{Mg} \cdot \mathrm{ha}^{-1}\right)$ that the data were not included in the analysis.

\section{Discussion}

The 1997 experiment was planted later than desired because of delayed delivery of transplants and some untimely rains. The shortened season reduced the potential for pruned plants to regrow and produce marketable fruit. Unander et al. (1991) and Jones (1993) emphasized the importance of an adequately long growing season to the success of a ratoon cropping system.

The 1997 experiment showed that a 6-cm difference in pruning height had little effect on yield (Tables 1 and 2). However, fruit number data in particular suggested that pruning below the main stem fork was too severe. Height of cutting influences the ratoon capacity of a crop by affecting both carbohydrate reserves and the number of buds left on the pruned plants for regrowth (Escalada and Plucknett, 1977). The 1997 experiment also showed that mowing was an effective method 
Table 2. Cumulative bell pepper fruit yields from post-pruning harvests, Bixby, Okla., in $1997^{2}$ and $1998^{\mathrm{y}}$.

\begin{tabular}{|c|c|c|c|c|c|c|}
\hline Treatment $^{x}$ & $\begin{array}{c}\text { U.S. } \\
\text { Fancy }\end{array}$ & $\begin{array}{l}\text { U.S. } \\
\text { No. } 1 \\
\end{array}$ & $\begin{array}{l}\text { U.S. } \\
\text { No. } 2 \\
\end{array}$ & $\begin{array}{c}\text { Total } \\
\text { marketable }\end{array}$ & Cull & Total \\
\hline \multicolumn{7}{|c|}{ Weight $\left(m g \cdot h a^{-1}\right) 1997$} \\
\hline Control & 0.4 & $6.0 \mathrm{a}^{\mathrm{w}}$ & $9.0 \mathrm{a}$ & $15.4 \mathrm{a}$ & $4.5 \mathrm{a}$ & $19.9 \mathrm{a}$ \\
\hline Mowed & 0.2 & $1.0 \mathrm{~b}$ & $3.9 \mathrm{~b}$ & $5.1 \mathrm{~b}$ & $2.7 \mathrm{~b}$ & $7.8 \mathrm{bc}$ \\
\hline Pruned $<$ MSF & 0.0 & $1.3 \mathrm{~b}$ & $1.6 \mathrm{c}$ & $2.9 \mathrm{~b}$ & $0.7 \mathrm{c}$ & $3.6 \mathrm{c}$ \\
\hline Pruned MSF + 1 & 0.2 & $2.2 \mathrm{~b}$ & $3.0 \mathrm{bc}$ & $5.3 \mathrm{~b}$ & $2.8 \mathrm{~b}$ & $8.1 \mathrm{~b}$ \\
\hline Pruned MSF + 2 & 0.4 & $1.6 \mathrm{~b}$ & $2.7 \mathrm{bc}$ & $4.7 \mathrm{~b}$ & $2.8 \mathrm{~b}$ & $7.6 \mathrm{bc}$ \\
\hline Significance & NS & $* *$ & $* *$ & $* *$ & $* *$ & $* *$ \\
\hline \multicolumn{7}{|c|}{ Count (thousands/ha) 1997} \\
\hline Control & 2 & $47 \mathrm{a}$ & $98 \mathrm{a}$ & $147 \mathrm{a}$ & $65 \mathrm{a}$ & $212 \mathrm{a}$ \\
\hline Mowed & 1 & $7 \mathrm{~b}$ & $44 \mathrm{~b}$ & $52 \mathrm{~b}$ & $33 \mathrm{~b}$ & $85 \mathrm{~b}$ \\
\hline Pruned $<$ MSF & 0 & $9 \mathrm{~b}$ & $20 \mathrm{c}$ & $29 \mathrm{~b}$ & $9 \mathrm{c}$ & $38 \mathrm{c}$ \\
\hline Pruned MSF + 1 & 1 & $17 \mathrm{~b}$ & $34 \mathrm{bc}$ & $52 \mathrm{~b}$ & $32 \mathrm{~b}$ & $84 \mathrm{~b}$ \\
\hline Pruned MSF + 2 & 2 & $12 \mathrm{~b}$ & $32 \mathrm{bc}$ & $47 \mathrm{~b}$ & $35 \mathrm{~b}$ & $82 \mathrm{~b}$ \\
\hline Significance & NS & $* *$ & $* *$ & $* *$ & $* *$ & $* *$ \\
\hline \multicolumn{7}{|c|}{ Weight $\left(m g \cdot h a^{-1}\right) 1998$} \\
\hline Control & $0.2 \mathrm{~b}$ & $8.4 \mathrm{a}$ & $21.3 \mathrm{a}$ & 29.9 a & $22.6 \mathrm{a}$ & $52.4 \mathrm{a}$ \\
\hline Mowed & $3.2 \mathrm{a}$ & $5.6 \mathrm{ab}$ & $6.1 \mathrm{~b}$ & $14.9 \mathrm{~b}$ & $8.0 \mathrm{~b}$ & $22.9 \mathrm{~b}$ \\
\hline June-set & $0.8 \mathrm{~b}$ & $3.0 \mathrm{~b}$ & $2.3 \mathrm{c}$ & $6.0 \mathrm{c}$ & $2.7 \mathrm{c}$ & $8.8 \mathrm{c}$ \\
\hline Significance & $* *$ & $*$ & $* *$ & $* *$ & $* *$ & $* *$ \\
\hline \multicolumn{7}{|c|}{ Count (thousands/ha) 1998} \\
\hline Control & $1 \mathrm{~b}$ & $72 \mathrm{a}$ & $260 \mathrm{a}$ & $333 \mathrm{a}$ & $337 \mathrm{a}$ & $670 \mathrm{a}$ \\
\hline Mowed & $19 \mathrm{a}$ & $40 \mathrm{~b}$ & $65 \mathrm{~b}$ & $124 \mathrm{~b}$ & $78 \mathrm{~b}$ & $201 \mathrm{~b}$ \\
\hline June-set & $4 \mathrm{~b}$ & $23 \mathrm{~b}$ & $26 \mathrm{~b}$ & $53 \mathrm{c}$ & $28 \mathrm{~b}$ & $81 \mathrm{c}$ \\
\hline Significance & $* *$ & $*$ & $* *$ & $* *$ & $* *$ & $* *$ \\
\hline
\end{tabular}

${ }^{2}$ Control plants were harvested 15 times between 14 July and 21 Oct. Mowed plants and hand pruned plants were harvested 11 times between 13 Aug. and 21 Oct.

${ }^{y}$ Control plants were harvested 14 times between 28 July and 26 Oct. Mowed plants and June-set plants were harvested five times between 28 Sept. and 26 Oct.

${ }^{\mathrm{x}}$ See Table 1 for explanation of treatment abbreviations.

"Mean separation within variables by Duncan's multiple range test, $P \leq 0.05$.

Ns, *, *** Nonsignificant or significant by $\mathrm{F}$ test at $P \leq 0.05$ or 0.01 , respectively.

Table 3. Cumulative bell pepper fruit yields from postmowing harvests, Uvalde, Texas, $1998^{z}$.

\begin{tabular}{lcccccc}
\hline \hline Treatment & U.S. & U.S. & U.S. & Total \\
mancy & No. 1 & No. 2 & Cull & Total \\
\hline Control & 0.0 & 4.0 & 11.5 & 15.5 & 7.8 & 23.2 \\
Mowed & 0.3 & 9.5 & 9.4 & 19.2 & 1.4 & 20.6 \\
Significance & NS & $*$ & NS & NS & $* *$ & NS \\
& \multicolumn{7}{c}{ Count (thousands/ha) } \\
Control & 0 & 28 & 134 & 162 & 145 & 308 \\
Mowed & 1 & 47 & 74 & 122 & 16 & 138 \\
Significance & NS & NS & $*$ & NS & $* *$ & $* *$
\end{tabular}

$\overline{{ }^{2} \text { Control plants were harvested on } 24 \text { Sept. and } 4 \text { Dec. Mowed plants were harvested on } 4 \text { Dec. }}$ ns, ${ }^{*}, * *$ Nonsignificant or significant by $\mathrm{F}$ test at $P \leq 0.05$ or 0.01 , respectively.

of pruning. Hand pruning was done to achieve precise cuts in terms of plant morphology, but never was intended as a potential commercial treatment since it would be costprohibitive for open field production of peppers.

The 1998 experiments further demonstrated the potential of the ratoon cropping system. Two potential concerns with mowed plants were subsequent plant death because of physical injury, and the spread of mechanically-transmitted plant viruses by the mower (Pategas et al., 1989). Although a few mowed plants did in fact die rather than recover and regrow, overall these concerns were not realized, as indicated by the observations of 29 Oct. 1998 at Bixby. The ratoon cropping system also was superior to planting in June or September specifically for fall crop production. Stand establishment was difficult in the heat of summer, and subsequent plant growth was erratic, as indicated by the rela- mium (U.S. Fancy and U.S. No. 1) fruit produced.

A nonquantified advantage of mowed plants was that their canopies were more easily managed compared with those of control plants. By Sept. 1998, the massive, dense canopies of nonmowed plants were an impediment to spray penetration, made it difficult to locate fruit, and were prone to branch lodging and breakage. These problems could potentially be overcome by supporting the plants with a stake-and-weave system, but labor costs would be greatly increased.

Maintaining spring-transplanted bell peppers is a viable technique for fall pepper production, and the highest total marketable yields may be obtained if plants are not mowed. However, mowing offers an opportunity for increased fall production of premium fruit, and mowed plants would be easier to manage than nonpruned plants. Growers may wish to experiment with different times and heights of mowing in order to customize the system to their conditions. An economic analysis might also be needed to determine whether the inputs required to continuously harvest marketable fruit from nonpruned plants (including removal and/or grading out of a large volume of cull fruit) are offset by the production of marketable (primarily U.S. No. 2) fruit that would be sacrificed if the plants were mowed.

\section{Literature Cited}

Beverly, R.B. and A.W. Byous. 1992. Ratoon cropping mechanically harvested lima bean is possible in the southern Piedmont. HortScience 27:269.

Chauhan, Y.S., C. Johansen, and S.C. Gupta. 1996. Assessment of ratoonability of short-duration pigeonpea genotypes. J. Agr. Sci. (Cambridge) 127:331-335.

Coale, F.J. and D.B. Jones. 1994. Reflood timing for ratoon rice grown on Everglades Histosols. Agron. J. 86:478-482.

Dhankhar, B.S., N. Mehrotra, and B.D. Chaudhary. 1980. Genetic divergence in normal and ratoon crops of eggplant. Indian J. Agr. Sci. 50:144-147.

Escalada, R.G. and D.L. Plucknett. 1977. Ratoon cropping of sorghum. III. Effect of nitrogen and cutting height on ratoon performance. Agron. J. 69:341-346.

tively low mean shoot fresh weights recorded at Bixby on 29 Oct. 1998.

Perhaps the most notable conclusion derived from the 1998 data is the efficiency of the mowed plants in producing marketable fruit. At Bixby, there were five harvests after mowing in the mowed plants vs. 14 in the control-yet the percentage of marketable fruit weight harvested after mowing was not affected (57\% in the control vs. $64 \%$ in the mowed treatment). The contrast was even more striking at Uvalde, where mowed plants yielded $93 \%$ marketable fruit by weight in one harvest after mowing vs. $66 \%$ from two harvests in the control, a difference significant at $P \leq 0.01$. In terms of absolute tonnage of marketable fruit, the control was equal or superior to the mowed treatment, but this was primarily due to greater production of U.S. No. 2 fruit. The data from both locations in 1998 show that mowed plants were equal or superior to control plants in weight of pre-
Irizarry, H., E. Rivera, and J.A. Rodriguez. 1992. Bunch and ratoon management for profitable production of high quality bananas (Musa acuminata, AAA). J. Agr. Univ. Puerto Rico 76(3/4):119-130.

Jones, D.B. 1993. Rice ratoon response to main crop harvest cutting height. Agron. J. 85:1139-1142.

McCormick, M.E., D.R. Morris, B.A. Ackerson, and D.C. Blouin. 1995. Ratoon cropping forage sorghum for silage: Yield, fermentation, and nutrition. Agron. J. 87:952-957.

Pategas, K.G., A.C. Schuerger, and C. Wetter. 1989. Management of tomato mosaic virus in hydroponically grown pepper (Capsicum aпnиum). Plant Dis. 73:570-573.

Unander, D.W., L.N. Aviles-Rodriguez, F. VarelaRamirez, and A. Acosta. 1991. Plant population and pruning of pepper cultivars. J. Agr. Univ. Puerto Rico 75(3): 199-204.

Yadav, R.L., S.R. Prasad, R. Singh, and V.K. Srivastava. 1994. Recycling sugarcane trash to conserve soil organic carbon for sustaining yields of successive ratoon crops in sugarcane. Bioresource Technol. 49:231-235. 